\title{
DISTRIBUTION AND ABUNDANCE OF THE EDIBLE ORCHIDS OF THE SOUTHERN HIGHLANDS OF TANZANIA
}

\author{
AMS Nyomora \\ Botany Department, University of Dar es Salaam, \\ P.O. Box 35060 Dar Es Salaam, Tanzania \\ anyomora@hotmail.com
}

\begin{abstract}
All orchids have showy flowers and many are therefore popular as exotic houseplants as well as contributing significantly to eco-tourism. A special attribute of some orchid genera is the production of edible tubers, an attribute that can contradict eco-tourism if harvesting is not done sustainably. Such is the case in the Southern Highlands where for example, Kitulo Plateau has been gazetted to be a National Park but where edible orchid harvesting is a serious conservation problem. Botanically, unsustainable harvesting can mean the loss of important germplasm even before some species are known to exist. A field survey was undertaken for three weeks in March 2002 in the Southern Regions of Tanzania (Iringa, Mbeya, Rukwa and Ruvuma) to study aspects of the extent of the distribution, diversity and density of edible orchids. Tools for identification included structured questionnaire, on-the-spot identification as well as using herbarium voucher samples and keys. Analytical tools included Shannons' diversity index and Canonical Community Ordination (CANOCO) and ANOVA in Microsoft Excel. A total of 13 edible species of orchids were documented during the survey all of them from the genera Habenaria, Disa and Satyrium. While Tandala and Molo hills had the highest species Diversity Index (over 1.2), Kitulo Plateau showed the greatest species density of over 200/30m ${ }^{2}$ quadrants. Local communities in Madaba in Ruvuma, Molo, and Mbisi in Rukwa regions used the orchids as vegetables and snacks in lieu of animal meat. The rest of the studied areas used orchids as a source of cash by selling to Zambian traders and or to their middlemen. More research is needed to monitor growth phases, reproductive/propagation studies as well as taxonomic and systematic studies preferably using molecular techniques to determine relationships amongst edible orchids and their non edible relatives.
\end{abstract}

\section{INTRODUCTION}

The Orchid family (Orchidaceae) represents the most advanced family in the Monocotyledoneae and is mostly adapted to the tropics (Frank 1968, Agnew and Shirley 1994). They comprise about 20,000-2500 species in several hundred genera making it one of the 3 largest families of Angiosperm. All forms of orchids are perennial epiphytes or terrestrial and occupy wide ranges of ecological habitats as well as exhibiting highly specialized morphological, structural and physiological characteristics (Dressler 1990) and most orchids have showy flowers. Some of the terrestrial types have tuberous, bulbous thickened roots that are edible. This category is addressed in this paper.
Various genera belonging to the orchid family including, Habenaria, Disa and Satyrium are known to form edible tubers (Davenport and Ndangalasi 2003) and Vanilla whose pods provide spices (Frank 1968). Habenaria, Disa and Satyrium are found in the Southern Tanzania (Cribb and Leedal 1982 Lovett et al. 1995 Temu and Chihongo 1998 Davenport and Ndangalasi 2003). Many economically important species of these genera that are common in Tanzania have yet to be identified.

All edible orchids are terrestrial and are characterized by stout stems arising from root tubers of various shapes. They occur in varied shapes, sizes and colours and inhabit 
Nyomora. - Distribution and abundance of the edible orchids ...

spectacular natural landscapes on the undulating hills and valleys that typify the Southern Highlands. Despite the differences, the flowers are typically orchidaceous i.e. having showy flowers with a corolla of 3 petals one of which is a labellum or lip that differs from the others and may be spurred as described by Kurzweil (2000). All are deciduous and the aerial stem dies back at the end of the wet season when the plant become dormant, to sprout again at the beginning of the rains from a single bud/'eye' at the apex of the storage mother tuber(s) that varies from 1-3.

Some orchids of Tanzania provide edible tubers from which a staple food known as 'Kikande', 'Chikanda' or Kinaka is made that is consumed by the Ngoni, Fipa, Nyiha and related tribes in neighbouring Zambia (Davenport and Ndangalasi 2003). Consumption in Zambia is increasing and now threatens orchid populations in Tanzania (Davenport and Ndangalasi 2003) due to over-harvesting ventures on the Tanzanian side.

None of these edible orchids have been included in the mainstream staples of Tanzania. Yet, it is known that these indigenous crops are very important in bridging the seasons of hunger to the next harvesting season and therefore can contribute to food security (Temu and Chihongo 1998).

One orchid tuber gives rise to only one plant by the vegetative means of reproduction. This coupled by a lack of information on the extent of seed viability and seedling survival, over-harvesting and the competition with pyrethrum and potato cultivation is endangering orchids. Possible domestication and conservation measures (in-situ and ex-situ) require knowledge of the germplasm available and this represents the focus of this study, which was aimed at determining aspects of the extent of distribution of edible 0rchids in the Southern Highland regions of Tanzania namely Iringa, Mbeya Ruvuma and Rukwa.

\section{METHODS}

\section{Sampling and identification}

A field survey was undertaken through 3-24 March 2002 in the Southern Regions of Tanzania. Visits were made to the District Forest/Natural Resources offices and selected villages in Njombe, Makete, Mbeya, Ileje, Mbozi and Sumbawanga although one of the routes from Kitulo through Iniho to Makete was not passable due to heavy rains (Figure 1).

A structured questionnaire was used to interview key informants including district and village council representatives and key players in the trade (harvesters, traders, consumers), followed by on site visits accompanied by the orchid collectors/harvesters to authenticate dialogues.

A total of 50 orchid stakeholders were interviewed including Natural Resource Officers, harvesters, and herdpersons/collectors. At each site, 3 sets of plant samples were collected for further identification. Such samples were carefully uprooted, prepared into specimen vouchers, dried and transported to the University of Dar es Salaam (UDSM) herbarium. One set was used for identification at UDSM herbarium using appropriate keys and existing comparison vouchers, one set was donated to through Ben Bytebier for names confirmation while the other was pressed and kept for future referencing. 


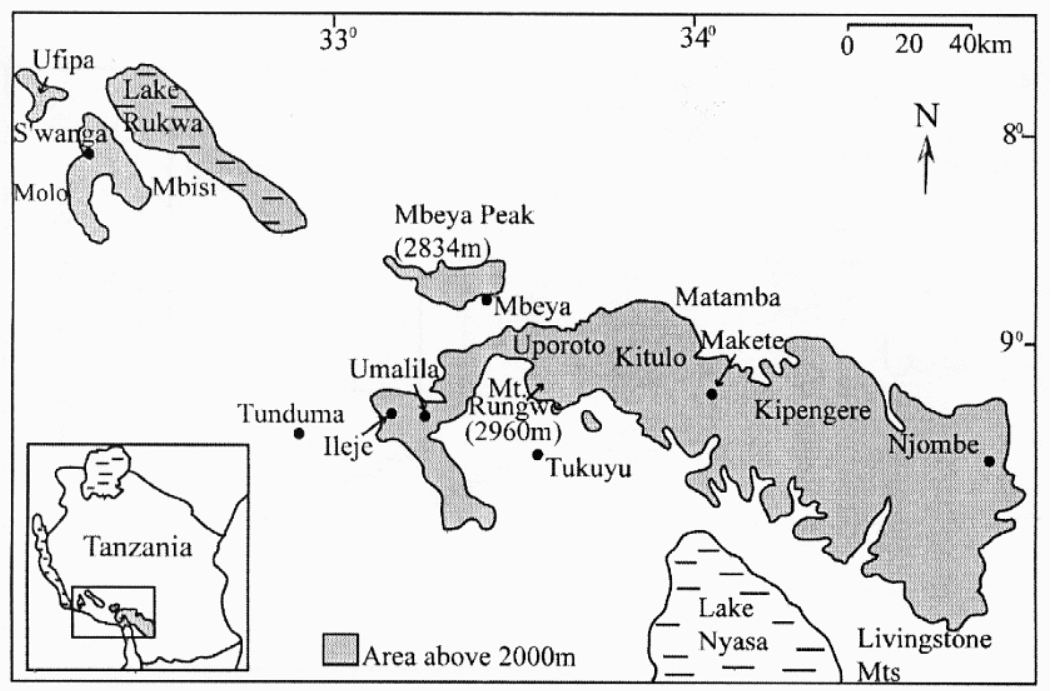

Figure 1: $\quad$ Map of the Southern Highlands of Tanzania (from Davenport and Ndangalasi, 2003)

\section{Distribution and Abundance}

At each representative site, 3 quadrants measuring $3 \mathrm{~m} \times 5 \mathrm{~m}$ were randomly made along a $250 \mathrm{~m}$ transect that took the landscape of the site into account. Orchid types and their numbers in each of the 3 quadrants were counted and recorded (Feinsinger 2002 Sutherland 2002). The resultant compiled data were used to calculate the species Diversity Index expressed as: $\mathrm{H}^{\prime}={ }_{-} \mathrm{P}_{\mathrm{i}} \operatorname{Ln} \mathrm{P}_{\mathrm{i}}$

Where $\mathrm{H}^{\prime}=$ diversity index; $\mathrm{Pi}=$ proportion of $i^{t h}$ species found at the sites.

The diversity indices from both sites were compared using a statistical test at 5\% probability (Zar 1984). Plant species abundance and distribution were analyzed using CANOCO package where the data Matrix (species x sites) was prepared using Microsoft excel spreadsheet to enable CANOCO 3.10 analysis (ter Braak 1987). While using CANOCO package, Principle Component Analysis (PCA) was chosen as a technique to show differences in species abundance among study sites.

\section{RESULTS AND DISCUSSION}

It was necessary that the survey be done in February-March when some of the plants were in flower but it was not the most convenient time for accessibility to some sites.

\section{Orchid types}

As presented in Table 1 and 2, a total of 13 edible orchid species belonging to the genus Habenaria (4 species), Satyrium (4 species) and Disa (5 species) were observed and identified during the ethnobotanical survey. These were Harbenaria cornuta Lindl., $H$. praestans Rendle, $H$. adolphii Schltr., $H$. Humilior Reichb.f., ; Satyrium sacculatum (Rendle) Rolfe, ; $S$. crassicaule Rendle, $S$. chlorocorys Rolfe and $S$. breve Rolfe; Disa walleri Reichb.f., ; D. erubescens Rendle, D. leucostachys Kraenzl., ; $D$. tanganyikensis Summarch., and $D$. aequiloba Summarh. This may represent only about $15 \%$ of the edible orchid species found in the area (Davenport and Ndangangalasi 2003). That all the orchid species found belonged to genus Habenaria, Satyrium and Disa is in agreement with the 
work of Leedal (1975), Cribb and Leedal (1982) whose general emphasis on all orchid species speculated as many as 200 species as well as Davenport and Ndangalasi (2003) whose study on the orchid trade in the Southern Highlands showed that over 4 million tubers are harvested each year and that as many as 85 species from these three genera are being harvested. Also found were 2 non-edible orchid species later identified as Pteroglossaspis eustachya Reichb.f. and Holothrix longiflora Rolfe. No vernacular names were given by the interviewee for these non-edible orchid species.

Table 1: Orchid species identified at visited locations in the Southern Highlands

\begin{tabular}{|c|c|c|c|}
\hline $\begin{array}{l}\text { COLL \# } \\
\text { FMM/AN }\end{array}$ & Species Name & $\begin{array}{l}\text { Vernacular } \\
\text { Name }\end{array}$ & Locality of collection \\
\hline 2286 & Disa walleri Reichb.f. & Chikanda & Mbeya (Umalila, Ilembo) \\
\hline 2287 & Disa erubescens Rendle & Chikanda & Ileje-Vwawa road \\
\hline 2288 & Harbenaria cornuta Lindl. & Chikanda & Ileje-Vwawa road \\
\hline $2289-90$ & Habenaria praestans Rendle & Chikanda & Mbeya (Umalila, Izonzo) \\
\hline 2292 & Habenaria adolphii Schultr. & Vinying'inya & $\begin{array}{l}\text { Songea (Madaba LITI \& } \\
\text { Mgendagenda village) }\end{array}$ \\
\hline 2293 & $\begin{array}{l}\text { Satyrium sacculatum } \\
\text { (Rendle)Rolfe }\end{array}$ & $\begin{array}{l}\text { Kikande, } \\
\text { MaseheleseheleVikan } \\
\text { dokando }\end{array}$ & Songea (Makimbija and Wino) \\
\hline 2294 & Disa walleri Reichb.f. & Masekelesekele & Njombe (Kifanya) \\
\hline 2295 & $\begin{array}{l}\text { Satyrium sacculatum } \\
\text { (Rendle)Rolfe }\end{array}$ & Chikanda & Njombe (Makoga village) \\
\hline 2296 & Disa erubescens Rendle & Chikanda & Kipengere \\
\hline 2297 & Disa tanganyikensis Summach & Chikanda & Makete (Tandala) \\
\hline 2298 & Disa erubescens Rendle & Chikanda & Makete (Tandala) \\
\hline 2299 & Satyrium crassicaule Rendle & Kikande & Makete (Tandala) \\
\hline 2300 & Satyrium chlorocorys Rolfe & Chikanda & Makete (Kitulo Plateau) \\
\hline 2301 & Disa leucostachys Rolfe & Chikanda & Kipengere grassland \\
\hline 2302 & Satyrium breve Rolfe & Chikanda & Kipengere \\
\hline 2303 & $\begin{array}{l}\text { Satyrium sacculatum } \\
\text { (Rendle)Rolfe }\end{array}$ & Chikanda & Tandala \\
\hline 2304 & Satyrium chlorocorys Rolfe & Chikanda & Makete (Kitulo Plateau), Matamba \\
\hline 2305 & Habenaria adolphii & Chikanda & Matamba \\
\hline 2306 & Satyrium crassicaule Rendle & Chikanda & Makete (Kitulo Plateau) \\
\hline 2307 & Disa walleri Reichb.f. & $\begin{array}{l}\text { Chikanda/ } \\
\text { Chechela }\end{array}$ & Rukwa (Molo hills Msandamuungano) \\
\hline 2308 & Satyrium chlorocorys Rolfe & Chikanda Jike & Rukwa (Molo hills) \\
\hline 2309 & $\begin{array}{l}\text { Pteroglossaspis eustachya } \\
\text { Reichb.f. }\end{array}$ & - & Rukwa, Msandamuungano \\
\hline 2310 & Habenaria humilior Reichb.f. & Chikanda & Rukwa (Molo hills) \\
\hline 2311 & Habenaria adolphii Schult. & Chikanda & Rukwa (Molo hills) \\
\hline 2312 & Disa walleri Reichb.f. & Chikanda/Dume & Rukwa (Mbizi hills) \\
\hline 2313 & Satyrium chlorocorys Rolfe & Chikanda jike & Rukwa (Mbizi hills) \\
\hline 2314 & $\begin{array}{l}\text { Satyrium sacculatum } \\
\text { (Rendle)Rolfe }\end{array}$ & Chikanda & Mbozi (Kisitu, Kapele) \\
\hline 2315 & $\begin{array}{l}\text { Pteroglossaspis eustachya } \\
\text { Reichb.f. }\end{array}$ & - & Mbozi (Chipumpu Ndalambo) \\
\hline 2316 & Disa erubescens Rendle & Masekendi & Mbozi (Chipumpu) \\
\hline 2318 & Disa equiloba Summarch. & Chikanda & Mbozi (Chipumpu Ndalambo, Kapele) \\
\hline
\end{tabular}

Collectors: FMM = Frank Mgala Mbago; AN = Dr. Agnes Nyomora 
Table 2: Field observation and interview's remarks on edible orchids found in their localities

\begin{tabular}{|c|c|c|c|}
\hline Village & $\begin{array}{l}\text { Orchid type/ } \\
\text { Vernacular name }\end{array}$ & Description & Interviewee's remarks \\
\hline Mgendagenda/ & $\begin{array}{l}\text { Vinying'inya } \\
\text { (Habenaria }\end{array}$ & $\begin{array}{l}\text { Two opposite oval leaves } \\
\text { pressed to the ground }\end{array}$ & $\begin{array}{l}\text { Not commercialized, tubers } \\
\text { harvested by women and }\end{array}$ \\
\hline Madaba & $\begin{array}{l}\text { adolphii } \\
\text { Schultr.) }\end{array}$ & $\begin{array}{l}\text { with a long inflorescence } \\
\text { bearing white } \\
\text { orchidaceous flowers } \\
\text { enclosed in bracts. Two } \\
\text { tubular tubers (current } \\
\text { year and a shriveled } \\
\text { previous year }\end{array}$ & $\begin{array}{l}\text { youth in the dry season for } \\
\text { local consumption }\end{array}$ \\
\hline Makimbija/ & Kikande & Stout stems with & Not currently eaten by the \\
\hline Wino & $\begin{array}{l}\text { Masehelesehele } \\
\text { Vikandokando } \\
\text { (Satyrium } \\
\text { sacculatum } \\
\text { (Rendle) Rolfe) }\end{array}$ & $\begin{array}{l}\text { alternate leaves clinging } \\
\text { to the stem. Small white } \\
\text { flowers enclosed in } \\
\text { larger green bracts. Two } \\
\text { globular tubers (old and } \\
\text { new }\end{array}$ & $\begin{array}{l}\text { locals. Youth harvested and } \\
\text { sold tubers to middlemen } \\
\text { coming from Mbinga district } \\
\text { at }(40,000 / \mathrm{sac}) \text { from } \\
\text { collectors starting from May } \\
\text { through October }\end{array}$ \\
\hline $\begin{array}{l}\text { Kifanya hills/ } \\
\text { Kifanya }\end{array}$ & $\begin{array}{l}\text { Masekelesekele } \\
\text { (Disa walleri } \\
\text { Reichb.f.) }\end{array}$ & $\begin{array}{l}\text { Purplish-maroon } \\
\text { coloured orchidaceous } \\
\text { flowers on a longish } \\
\text { inflorescence originating } \\
\text { from labrous leaves }\end{array}$ & $\begin{array}{l}\text { Not currently eaten. Youth } \\
\text { harvested and sold tubers to } \\
\text { middlemen coming from } \\
\text { Mbinga district at TzSh. } \\
40,000 / \text { sac. It is a commercial } \\
\text { venture. }\end{array}$ \\
\hline $\begin{array}{l}\text { Matwaki/Kipe } \\
\text { ngere }\end{array}$ & Maseke & $\begin{array}{l}\text { Bright orange flowers on } \\
\text { a flower inflorescence } \\
\text { overlapped by broad } \\
\text { alternating leaves }\end{array}$ & $\begin{array}{l}\text { Not eaten but youth and } \\
\text { women harvest and sell tubers } \\
\text { to middlemen from Njombe } \\
\text { district. Seedlings seemed to } \\
\text { colonize an area around } \\
\text { mother plants indicative of } \\
\text { seed germinability/viability. } \\
\text { The montane grassland on } \\
\text { these hills was not as thick as } \\
\text { the one found over the Kitulo } \\
\text { plateau }\end{array}$ \\
\hline $\begin{array}{l}\text { Tandala } \\
\text { (Mangoto, } \\
\text { Ibaga) }\end{array}$ & Maseke & Same as above & $\begin{array}{l}\text { One female had planted some } \\
\text { in her shamba and were yet to } \\
\text { give tubers. Maroon coloured } \\
\text { orchids tended to colonize a } \\
\text { patch where found around } \\
\text { older mother plant }\end{array}$ \\
\hline $\begin{array}{l}\text { Kitulo plateau } \\
\text { East } \\
\text { Njombe } \\
\text { district }\end{array}$ & Chikanda/Ligosi & $\begin{array}{l}\text { Bracts exposed orange } \\
\text { coloured compact } \\
\text { inflorescence } \\
\text { Yellow coloured were } \\
\text { named 'ligosi' } \\
\text { white coloured orchids } \\
\text { tended to colonize }\end{array}$ & $\begin{array}{l}\text { The white coloured were too } \\
\text { many to be accounted for } \\
\text { only by mother-plants alone, } \\
\text { probably had higher viability } \\
\text { than others. } \\
\text { Major collectors were women, } \\
\text { old folks and youths, sold to } \\
\text { traders from Tunduma }\end{array}$ \\
\hline
\end{tabular}




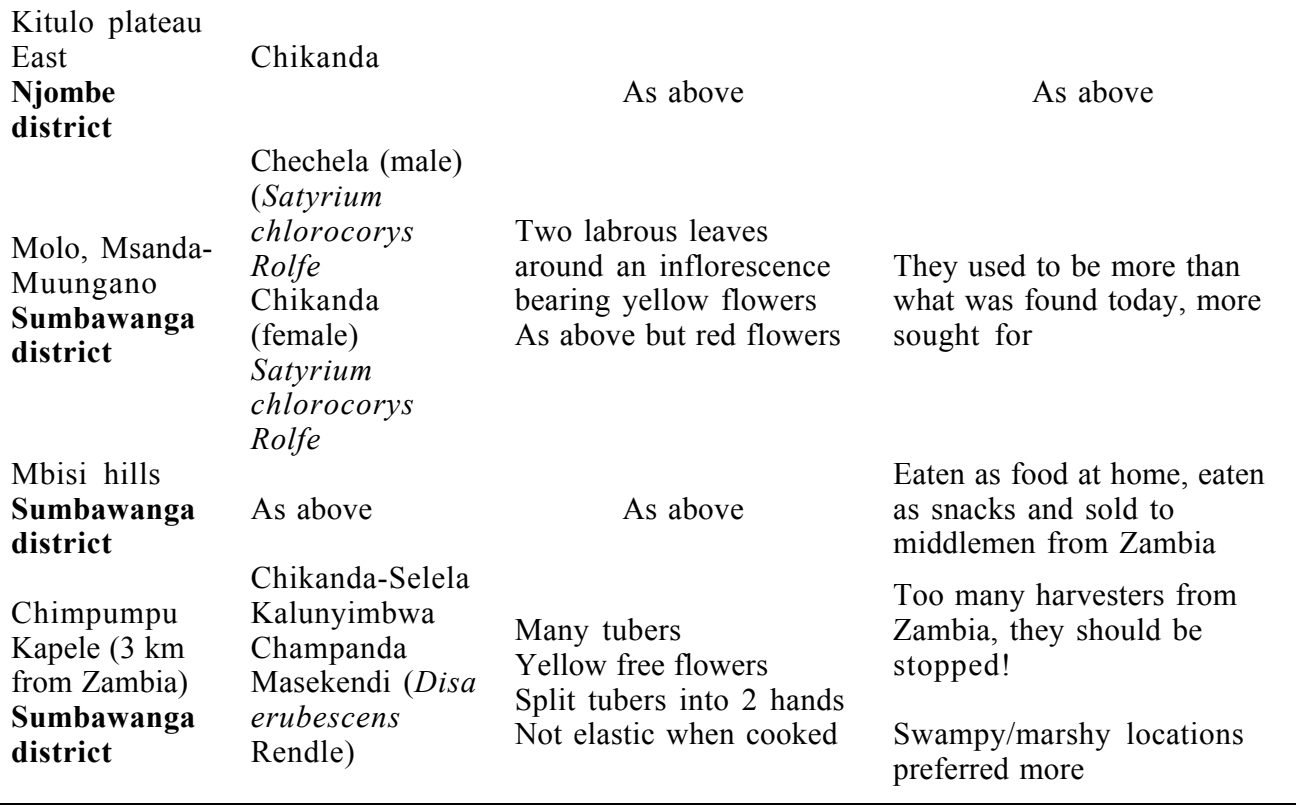

\section{Ecology/Habitat}

No orchids were observed from Mbeya southward towards Santilya possibly due to intensive cultivation. Could also be that they flowered during different season since many terrestrial orchid species, including Disa, Satyrium and Habenaria may flower at times other than March. Some orchids were observed around Ilembo in Umalila mountain range where it was learnt that it was becoming more and more difficult to get edible orchids in those mountains due to over-harvesting. Except for the occasional $H$. adolphii (Fig. 2a), the merging montane grassland from Umalila into miombo woodlands towards Mbozi was without much edible orchids. Edible orchids later identified as $H$. adolphii Schltr., were observed in the miombo woodland offChimala escarpment towards Uwanji.

The Kitulo Plateau from Matamba through DAFCO farm and Ipelele was clothed with mixed coloured orchids from white, yellow, and maroon orange to brick red (Fig 2b). The route taken through Bulongwa did not show orchids possibly due to the prevalence of thick forests and intensive cultivation up to Makete. From Makete, orchids were visible in the montane grassland $10 \mathrm{~km}$ from Tandala towards Kipengere, Makoga and Njombe. The Makambako to Njombe stretch was without edible orchids up to Kifanya where again edible orchids were observed through Wino to Madaba in Songea. Edible orchids appeared to flourish much more in montane than the savannah grassland, miombo woodlands and thickets as well as the riverine habitats that abounds the region. Few orchids were found deep into the dense tropical forests habitats that occasion the plateau in the Southern Highlands (Bulongwa and Mbisi hills). The orchids found in Rukwa region (South-west Mbozi, Molo, and Mbisi hills) were the same as those found in Kipengere (Figure $2 \mathrm{c}, \mathrm{d}, \mathrm{e})$. 


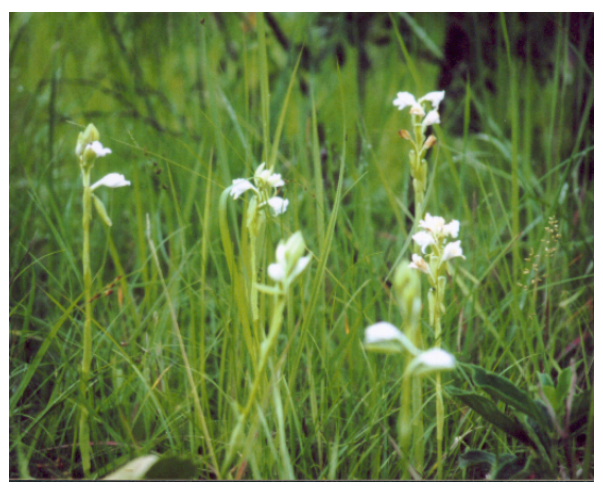

a

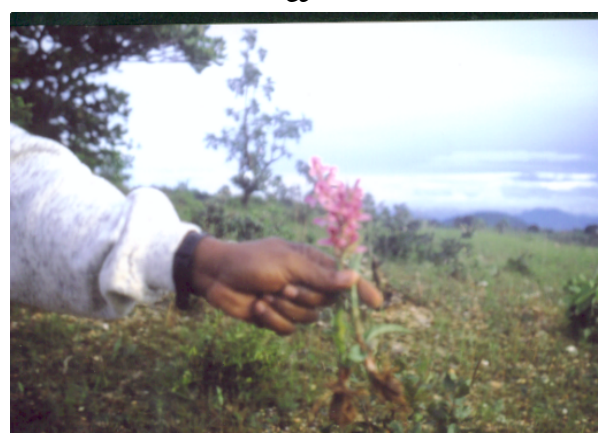

c

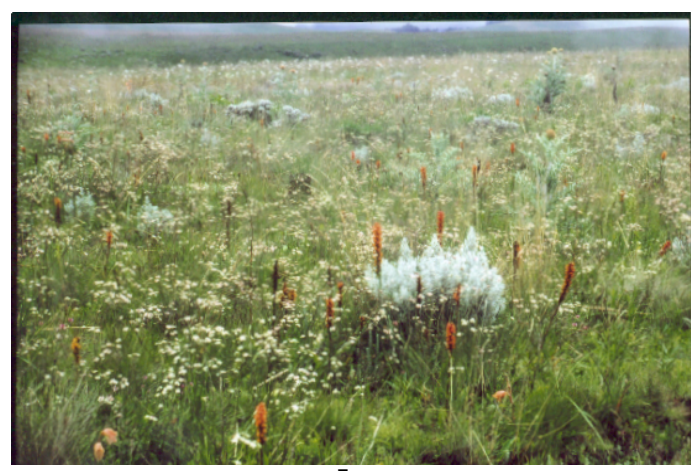

b

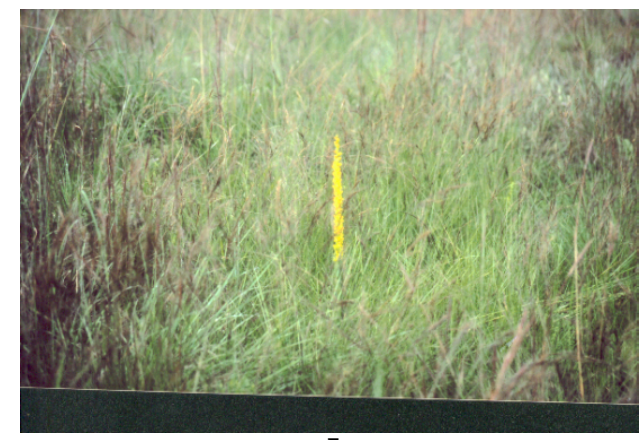

d

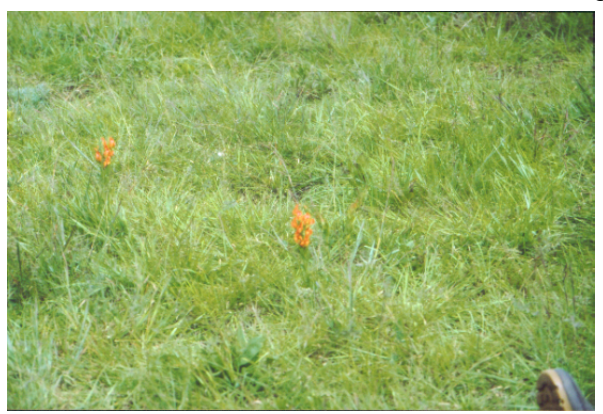

$\mathbf{e}$

Figure 2: $\quad$ Species of orchids from various sites (a: Habenaria adolphii Schltr, b: Satyrum spp. c: Disa usambarensis d: Disa spp. e: Disa walerri)

\section{Species abundance and density}

All edible orchid species recorded during this survey were from the genera Satyrium, Disa and Habenaria. This is consistent with various reports on edible orchids in the Southern Highlands (Davenport and Ndangalasi, 2003) and supported by other findings in the Southern Tanzania (Cribb and Leedal 1982, Lovett et al 1995, Temu and Chihongo 1998).
Mean species diversity was highest at Tandala $(1.283 \pm 0.035)$ followed by Molo hills $(1.255 \pm 0.062)$. These two sites are located in the montane grassland. The Matamba study areas found in miombo woodlands recorded the lowest species diversity index of less than 0.4 comprising only of H. Adolphii Schltr., (Figure 3). The variation in species diversity was found to 
be statistically significant $(\mathrm{P}<0.05)$ using $\mathrm{t}-$

test.

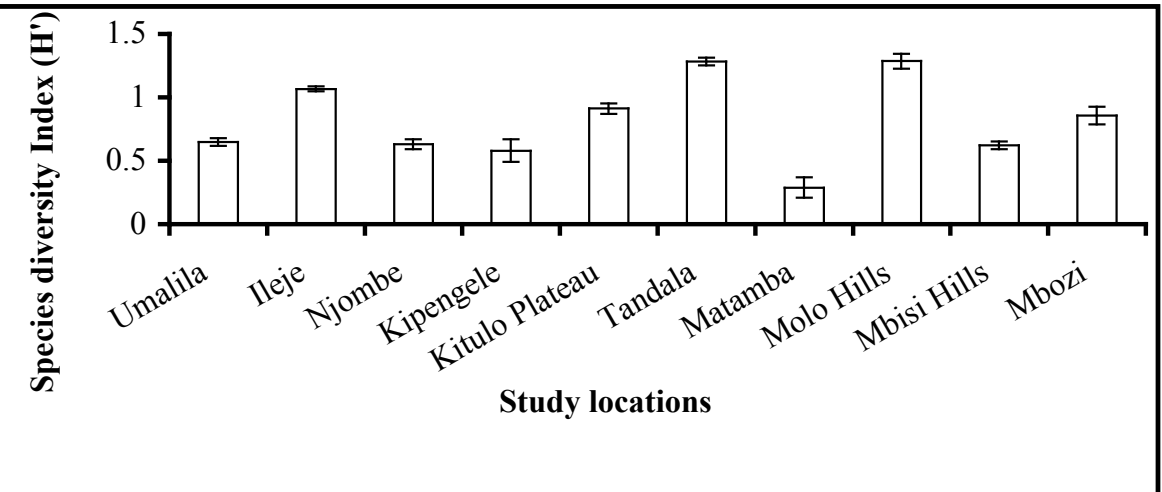

Figure 3: Variation in edible orchids species diversity at studied locations in the Southern Highlands of Tanzania

Kitulo plateau with its typical montane grassland and volcanic clay soil had the highest orchid species richness with over 200 plants $/ 30 \mathrm{~m}^{2}$ quadrants followed by Matamba and Tandala in that order. The lowest species richness was found in Madaba and Wino both located in the miombo woodlands. Mbozi, Umalila and Ileje had moderate richness of about 30 plants $/ 30 \mathrm{~m}^{2}$ quadrants (Figure 4 ).

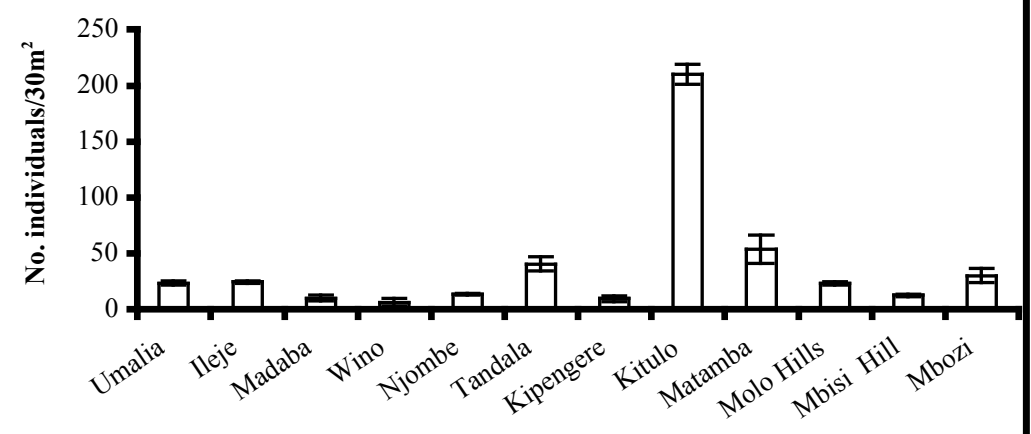

Study Locations

Figure 4: Variation in edible orchid orchid species richness at the study sites in the Southern Highlands of Tanzania 


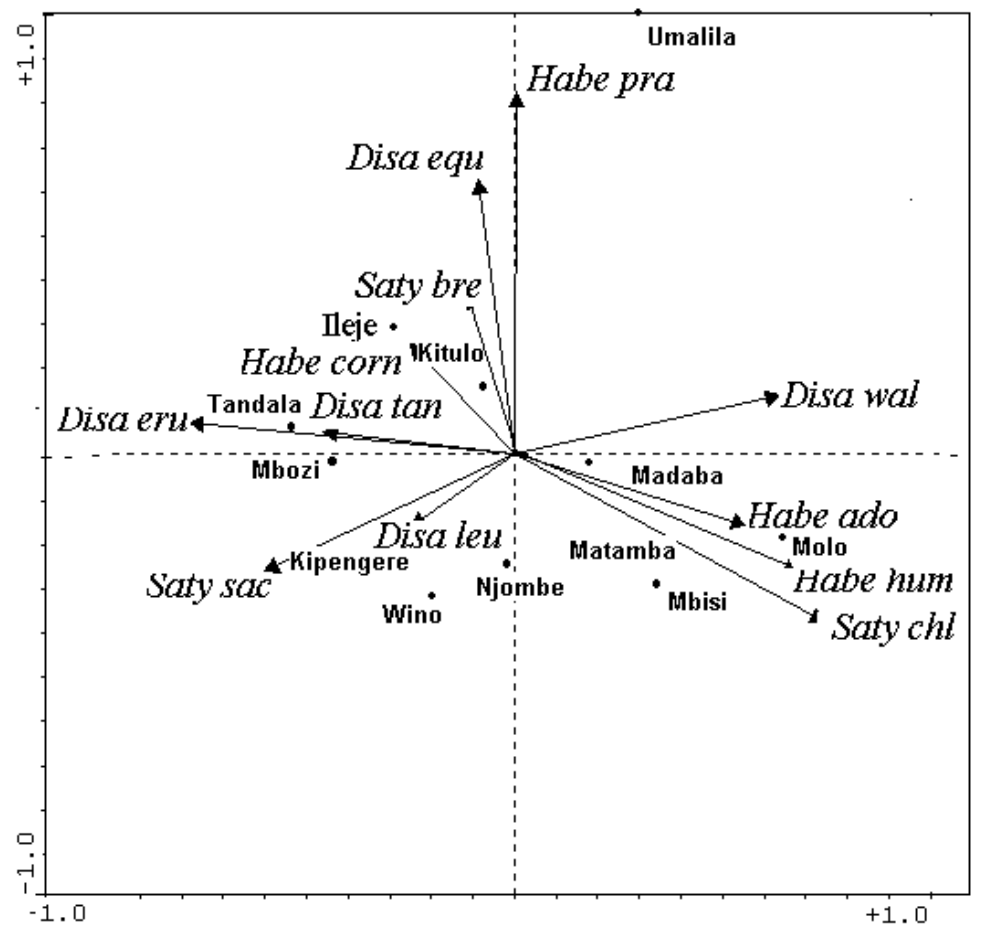

Figure 5: Ordination diagram of sites (bold) and species (Italic) distribution

Disa walleri, $H$. Adolphii Schltr., and $H$. Humilior Reichb.f., were the most abudant species in Madaba and Molo hills but less in Matamba, Umalila and Mbisi hills. Likewise, Ileje, Kitulo had high abudance of $D$. erubescens, $H$. cornuta Lindl.,and $S$. breve Rolfe but less in others. Mbozi and Tandala contained high abundance of $D$. erubescens, D. tanganyikensis Summarch., but less abundance of $S$. chlorocorys Rolfe and $S$. sacculatum (Rendle) Rolfe, that were more abundant in the Kipengere study area (Figure 5).

\section{Orchid use}

Local communities in Madaba, Molo and Mbisi used the orchids as vegetables and snacks in lieu of animal meat, the rest of the studied areas used orchids as source of cash by selling to Zambian traders and or their middlemen. Many holes depicting last year's harvest were seen on the Kitulo plateau, Mbisi and Mbozi vicinities possibly due to their relative densities of orchids and the proximity and accessibility to the Zambian market. Some interviewee contended that tubers harvested in Mbozi and Mbisi hills had better cooking quality and were highly sought after by Zambian traders than those from Kitulo.

\section{Recommendations and Future research}

Evidence for over-harvesting was obvious but trade should not be prevented particularly at village level since it is a source of needed cash. Rather, orchid trade need to be controlled by sensitizing the villagers about the importance of orchids as part of natural resources heritage to attract tourism to the area as well as instituting some regulatory mechanism. This should be done hand in hand with in-situ and ex-situ conservation measure efforts by relevant government institutions and NGOS. Following research areas are suggested: Monitoring of growth phase of edible 
orchids to ascertain periods of tuber formation and seed set. Studies on sexual propagation are also required to determine conditions for seed viability and germination as well as studies on vegetative multiplication (micropropagation). Phylogenetic studies at conventional systematics and molecular level also should be undertaken so as to have a full characterization of the orchid germplasm found in the Southern Highlands.

\section{ACKNOWLEDGEMENT}

The author is indebted to the generous fund provided by Sida/SAREC through the Core Support to the Faculty of Science, UDSM. The technical support given by the Herbarium technician Frank Mbago and of the Postgraduate student Cosmas Mligo is also highly appreciated.

\section{REFERENCES}

Agnew A D Q and A Shirley (1994) Upland Kenya Wild Flowers: A flora of ferns and Herbaceous flowering plants of Upland Kenya $2^{\text {nd }}$ Edition. East Africa Natural History Society Cribb P J and Leedal G P (1982) The mountain flowers of Southern Tanzania A A Balkema Rotterdam, IX 244pp.

Davenport TR B and H J Ndangalasi (2003) An escalating trade in orchid tubersacross Tanzania's Southern Highlands: Assessment, dynamics and conservation implications. Oryx 37(1): 55-61.

Dressler R L (1981) Natural History and Classification. 332pp. Harvard University

\author{
Press, Cambridge \\ Feinsinger P (2001) Designing Field \\ Studies for Biodiversity \\ Conservation. Island Press. \\ Washington, Covelo, London \\ Frank (1968) Orchids of East Africa. Verlag \\ Von. J. Cramer, Lehre, Germany. \\ Kurzweil H (2000) Orchids in Southern \\ Africa. National Botanical Institute \\ of South Africa \\ www.plantzafrica.com/plantnop \\ orchids/maps.htm
}

Leedal G P (1975) Useful plants of the Southern Highlands of Tanzania. Unpublished report.

Lovett J C R E Gereau and K J Sidwell (1995) Vegetation and Phytogeography of the Kitulo Plateau, Southern Tanzania. Proceedings of the XIIth AETFAT Congress, Zomba, Malawi.

Sutherland W.J. (2001) Ecological Census Techniques. A Handbook. Cambridge University Press, UK.ter Braak, C.F.J. (1987). CANOCO:- a FORTRA programme for Canonical community ordination by (Partial) (Detrenched) correspondence analysis. Principal components analysis and redundancy analysis. TNO, Wageningen.

Temu R P C and A Chihongo (1998) Field survey of wild and underutilized edible plants of Ruvuma Region, Tanzania. Unpublished report

Zar J H 1984 Biostatistical Analysis 2nd edition. Prentice Hall International, Inc. 